\title{
A housing supply absorption rate equation
}

\author{
Cameron K. Murray*
}

January 3, 2023

\begin{abstract}
What is the optimal rate of new housing supply? We answer this question with a simple model of new housing supply where the choice variable is the rate of new housing lot sales. This model is informed by the cost-side assumptions of the static equilibrium model but allows for demand for home-buying to vary over time. It differs from static models of housing production equilibrium by assuming that landowners hold land assets that are sold in asset markets to create new supply. Landowners maximise the present value of their balance sheet by choosing a rate of new housing lot sales, accounting for the effect on asset price growth from their sales in a housing market of finite depth. The resulting absorption rate equation has radically different parameter effects compared to the popular static housing density model. Constraints on density, for example, increase the optimal rate of supply by reducing the return to delaying development. Interest rates, land value tax rates, and demand growth, positively relate to the optimal rate of supply. The policy lessons are (1) the relationship between demand growth and the optimal supply rate limits the ability for market supply to reduce prices, and (2) increasing the cost to delaying housing development is the primary way to increase the market rate of housing supply.
\end{abstract}

Keywords: Absorption rate, housing supply, planning regulations.

JEL Codes: R31, R38, R52

\footnotetext{
*Henry Halloran Trust, The University of Sydney, Camperdown NSW 2006. Email: c.murray@sydney.edu.au This project was funded by the Henry Halloran Trust. https://sydney.edu.au/henry-halloran-trust/

Thanks to Thomas Aubrey, Troy Presley, Graeme Guthrie, Karl Fitzgerald, Peter Tulip, and Fergus Cumming for comments on early drafts.
} 


\section{A housing puzzle}

You are a housing developer with a large plot of land on the fringes of a major city with no planning constraints. How quickly should you sell these lots to supply them to the housing market?

Housing academics do not have a good answer to this question. ${ }^{1}$ Housing developers have rules of thumb. Yet despite the uncertainty about what factors determine the rate of new housing supply, radical policy changes are being considered in many cities, states and countries around the world to entice faster housing supply from private landowners. ${ }^{2}$

There is, however, a name for this rate of supply; the absorption rate. ${ }^{3}$ Our answer to the absorption rate puzzle is that the optimal rate of new housing supply is best represented by Equation 1.

$$
\text { Absorption Rate }=q_{t}^{*}=\frac{1}{2 a}\left(\dot{d}_{t}+\frac{(i+\tau)}{\omega}\right)
$$

The new approach that leads to Equation 1 is to consider housing supply as a dynamic problem of maximising the present value of a landowner's balance sheet via the choice of the rate of sale of new housing lots (either horizontally subdivided housing lots or vertically subdivided apartment lots).

According to our approach, the optimal per-period rate of new dwelling lots to supply is positively related to housing asset demand growth, $\dot{d}_{t}$, the prevailing interest rate, $i$, and the rate of land value tax, $\tau$, and the market depth of the housing market (1/a representing market trading depth). It is negatively related to the cost-efficiency of increasing housing density, represented by $\omega$.

The intuition here is that new housing lots are assets, and supplying (selling) them to the market is an asset swap of land for cash. It does not matter whether a dwelling structure is built by the seller or the buyer of the lot; an asset swap of cash for construction is immediately reversed upon sale of developed housing. In Australia, for example, almost all new dwellings are sold by private housing developers rather than retained, and the prevailing business model is a build-to-order method with sales driving production rates (Murray, 2020a,c)

Because housing is an asset in a market with a finite trading depth, additional lot or house sales in a period of time will affect price growth, limiting the market rate of housing absorption (see

\footnotetext{
${ }^{1}$ Over two decades ago DiPasquale (1999) noted that

Virtually every paper written on housing supply begins with some version of the same sentence: while there is an extensive literature on the demand for housing, far less has been written about housing supply. Although this statement is clearly true, at this point, there have actually been a considerable number of papers on housing supply. However, the empirical evidence on the supply of housing is far less convincing than that on the demand for housing. (p.9)
}

Little has changed. Indeed, the cost-based approach to housing supply, such as used in Glaeser \& Gyourko (2018), remains dominant despite being repeatedly discredited (Murray, 2020b; Somerville, 2005; O'Flaherty, 2003).

${ }^{2}$ The academic debate surrounding the effect of planning changes on the rate of housing supply and prices remains hotly contested (Manville et al., 2020; Rodríguez-Pose \& Storper, 2020; Cowan, 2019; Monkkonen, 2019; Wiener, 2020; Manville, 2019; Wegmann, 2019). Despite this, the pop-culture position seems to be that planning has extremely large effects on housing affordability (see, for example, Cowan (2019) and Yglesias (2012)), and has resulted in many planning reform proposals (MHCLG, 2020; Wiener, 2020; Hansen, 2020).

${ }^{3}$ As described in the studies of housing supply studies of Murray (2020c) and Letwin (2018). The absorption rate puzzle applies to any single subdivision and also across the set of feasible and allowable development sites in a region. 
Letwin (2018)). The rate of supply is increased until the marginal benefit from supplying at that rate now equals the marginal cost from selling at that rate later. The marginal benefit now comes from converting the housing lot asset to a cash asset and is the interest return on the lot sale price and property tax savings compared to retaining ownership. The marginal cost later comes from the effect of sales today on housing asset price growth, and hence on the value at which the later housing lots can be sold. In short, the development market will limit the rate of new housing supply independently of the optimal or allowable development density because new housing production responds to asset market conditions.

Our model is motivated by the observed behaviour of housing developers. Murray (2020c) showed that landbanks held by developers are managed as assets, not inventories, and supplied in response to housing asset market conditions. For example, one housing developer in that study owned 56,000 apartment lots on appropriately zoned sites but planned to supply only 1,000-2,000 per year (a 28-56 year pipeline) (Lendlease, 2019). Letwin (2018) also found that the rate of sales per period that developers were willing to make was a limiting factor for overall housing supply. To explain this behaviour our approach differs from static equilibrium models of housing density such as the Alonso-Muth-Mills formulation. The competitive static equilibrium model solves for an endogenous price level that clears the housing market in a region where housing stock adjusts instantly and continuously to demand shocks. Here instead we model the adjustment process of the expansion of lots used for housing, assuming an asset market of finite depth where all sales of new housing lots have observable price growth effects.

This paper explains how we arrived at this formulation of the absorption rate. First, in Section 2 we describe the theoretical issues in the housing supply literature, specifically the division between static and dynamic modelling approaches. We then describe in Section 3 the static model, and in Section 4 demonstrate how the static model implies certain dynamics if prices are not determined by a static equilibrium. In Section 5 we develop a maximisation problem where the rate of new supply is the choice variable for maximising the value of the flow of economic returns from new housing lot sales. In Section 6 we compare our results to static models to discuss the policy implications.

\section{Theoretical issues}

Static models of housing supply assume that all space in a region is developed once, simultaneously, while facing diseconomies of housing density. In the equilibrium, the sum of housing densities across all locations in a model region is the total housing stock. ${ }^{4}$ The responsiveness of the housing stock to price changes, known as the elasticity of supply, is related in this model to the rising-costs of higher density development, or planning controls on the density or location of housing development, which adds land input costs to each new dwelling.

In contrast, dynamic housing supply models based on capital budgeting and real options approaches assume that landowners face a joint decision about development timing and density, with the timing decision being the key to the overall rate of new housing supply (change in the stock). ${ }^{5}$ In these models, the effect of policy and market parameters on housing supply can be reversed compared to static models. For example, the effect of higher interest rates in Capozza

\footnotetext{
${ }^{4}$ For example, this is the result of the canonical Alonso-Muth-Mills model of a mono-centric city, which is widely used and forms the theoretical backbone of most analysis of housing supply (Kendall \& Tulip, 2018; Gyourko \& Molloy, 2015; Paciorek, 2013; Quigley \& Rosenthal, 2005; Glaeser et al., 2005; Brueckner et al., 1987)

${ }^{5}$ For example Lange \& Teulings (2018); Murphy (2018); Jou \& Lee (2007); Capozza \& Li (2002, 1994); Tse (Jul 1998); Titman (1985).
} 
\& Li (2002) is to increase the rate of supply. Additionally, in dynamic models price growth becomes a crucial input to supply decisions. For example, Murphy (2018) showed that "rising prices make building today more attractive, but also make waiting more attractive, thus reducing the responsiveness to price", echoing Lange \& Teulings (2018) who noted that "investment should be delayed when growth is high."

Static models predominantly influence housing policy, especially the push to relax planning limits on density, despite known parameter effect reversals in dynamic models (Manville, 2019; Glaeser \& Gyourko, 2018; Kendall \& Tulip, 2018; Lees, 2018; Kulish et al., 2012; Murray, 2020b). In Titman's (1985) real-options approach, density constraints can increase the rate of new housing supply by reducing the payoff from delaying and the change to build higher density in the future. Jou and Lee's (2007) analysis goes further, noting that density constraints may increase or decrease the rate of new housing supply depending on their relative effect on rents and the return to delaying development.

The policy supremacy of static models is a problem as they do not differentiate between density (dwellings per unit of land) and the rate of new supply (new dwellings per period of time). ${ }^{6}$ It is common for density limits to be called supply constraints even though they do not restrict the rate of new housing supply. This distinction is important, as the housing stock only adjusts via the rate of new housing supply per period, regardless of the density of that supply. This adjustment process is the domain of dynamic models focus on the differential returns from waiting or developing. Fortunately, these dynamic issues are now getting attention in policy discussion. For example, Letwin (2018) saw that the "market absorption rate", or the rate of new dwelling sales per period that developers are willing to make, was a limiting factor for new housing supply. This absorption rate appeared to depend on the effect of faster sales on land values in the housing asset market - higher rates of sale require lower prices, reducing the value of subsequent sales and of the development site. Evidence in (Murray, 2020c) showed that housing developers managed their undeveloped land banks as part of their capital portfolio, not as inventory, suggesting that asset returns were guiding new housing supply decisions.

We fill a gap by developing a simple deterministic absorption rate formula that is consistent with the static model optimal density model regarding the diseconomies of density, but that accounts for economic returns from capital growth prior to development. An original contribution is to incorporate a finding from asset market literature that there are linear price effects from trading volumes (Cont et al., 2013; Gatheral \& Schied, 2013). For lumpy, location-specific, housing, these price effects will constrain the total volume of new housing able to be produced in a period (as claimed by housing developers in Letwin (2018)). Doing so clarifies how and why parameter effect reversals happen when looking at the rate of new housing asset supply compared to optimal housing density, and why these effects are important for housing policy.

\section{The static housing stock model}

The theory of housing supply in static models assumes that the representative landowner maximise profits subject to diseconomies to housing density, $D$ (dwellings per land area, or $D=Q / L$ ). Since the equilibrium assumption is that all land is developed simultaneously to the most prof-

\footnotetext{
${ }^{6}$ As Pines (1989) notes, the static approach "is useless in explaining many stylized facts regarding the urban structure and its evolution through time. In the static analysis... land is continuously utilized within the city boundaries and the city boundaries are continuously extended with income and population size...The reason for the failure of the static model in explaining these 'irregularities' is that the housing stock is assumed to be perfectly malleable, which, of course, is highly unrealistic."
} 
itable density, housing density multiplied by land area is interpreted as the total housing stock. We derive a simple version of the standard model of Brueckner et al. (1987) for a fixed unit of land area (i.e. $L=1$ ) with uniform amenity to demonstrate the main features. Because the model is static, costs and prices can be interpreted either as a per-period flow or the capitalised value of that flow. We denote the capital value housing and the annual housing gross rent to be $P$ and $p$ respectively. Land capital value and land annual rental flow are denoted $R$ and $r$. The stock of dwellings is $Q$ and the flow of new dwellings is $q .^{7}$

Economic profits are revenue minus development costs and land value

$$
\pi=P(D) D-C(D)-R
$$

where $c(D)$ is a cost curve that exhibits increasing marginal costs (i.e. $\frac{d C}{d D}>1$ ). We assume a standard functional form in our exposition; $C(D)=C_{F C} D^{\beta}$, where $\beta>1$ captures the increasing per dwelling cost with density. The effect of per-dwelling fixed costs, such as development or impact fees, is captured in $C_{F C}$. Land value, $R$, is a derived value and is assumed not to add to the cost of higher density; it is merely the residual of total revenue less total development cost under a zero economic profits assumption.

On the demand side, we adopt the conventional Cobb-Douglas utility function where housing service demand for a fixed population of consumers with their incomes is modelled based on budget shares. If $u=n u m^{1-\alpha} \times Q^{\alpha}$, where num is the numeraire non-housing good and income. Using the well-known fixed budget shares solution we establish the relative housing price compared to the numeraire of $p(Q)=\alpha y / Q$. This setup provides the rental price of a unit of housing relative to the numeraire as a function of the stock of housing, $Q$. If we assume a fixed rate of rental price capitalisation into housing asset price, then we can also assume $P(Q)=p(Q)$.

The competitive market equilibrium is where price equals marginal cost. Marginal cost, $\frac{d C}{d D}$, is $\beta C_{F C} D^{\beta-1}$, and price is $P(Q)=\alpha y / Q$. Since we have assumed $L=1$, then $Q=D$ and the equilibrium housing stock and density is

$$
Q^{*}=D^{*}=\left(\frac{C_{F C} \beta}{\alpha y}\right)^{-\frac{1}{\beta}}
$$

In this equilibrium, all profitable development options are taken up and there is no further new supply (the stock is fixed). Comparative statics are used to compare housing stock equilibria at different parameter values. In the spatial equilibrium version, demand varies with location creating optimal density variation, but the same logic holds. The equilibrium housing stock rises with income, $y$, housing preferences, $\alpha$, and falls with diseconomies of density, $\beta$, and per-dwelling fixed costs, $c_{F C}$.

We have so far assumed a fixed unit land area to simplify the model. Now we examine how variation in available housing land affects price and dwelling stock. Changing the land area available affects the cost of dwellings as total cost is a function of density, $Q / L$, yet it does not

\footnotetext{
${ }^{7}$ There is often confusion in the housing supply literature between the rental price of a dwelling and the capital value of a dwelling. A divergence between these prices cannot be attributed to supply-side effects; they must be due to asset-pricing factors, such as low interest rates or growth expectations.
} 
affect the demand. Replacing $D$ with $Q / L$ in the cost function, $C(D)=C_{F C} D^{\beta}$, and deriving with respect to dwelling stock gives a supply curve in the following form.

$$
\frac{d C}{d Q}=\frac{1}{L} \beta C_{F C}\left(\frac{Q}{L}\right)^{\beta-1}
$$

Increasing land area available for housing, such as through rezoning, therefore shifts the supply curve downwards in this model ( $L$ is in the denominator both time is appears in Equation 4 ), potentially having large price and quantity effects. Figure 1 shows the comparative statics of assessing a change to land area and change in demand in this model. Equilibrium price and quantity for demand curve $D_{1}$ and a supply curve $S_{L=1}$ is Point A. Increasing the available housing land shifts the supply curve to $S_{L=2}$, as expected by Equation 4 generating a new equilibrium with a higher dwelling stock and lower price at Point B. A demand shift from this point to $D_{2}$ creates a new Point C equilibrium.

Because dwellings are durable, the supply curve is assumed to be kinked at the equilibrium. The vertical part of the curve below the kink reflects the willingness to supply existing homes at a price below cost in order to minimise losses on sunk investments after a negative demand shock. The comparison of the $\mathrm{C}$ and $\mathrm{D}$ equilibrium in Figure 1 demonstrates how the model would be used to compare a demand shock from $D_{2}$ to $D_{1}$ given the $S_{L=2}$ supply curve.

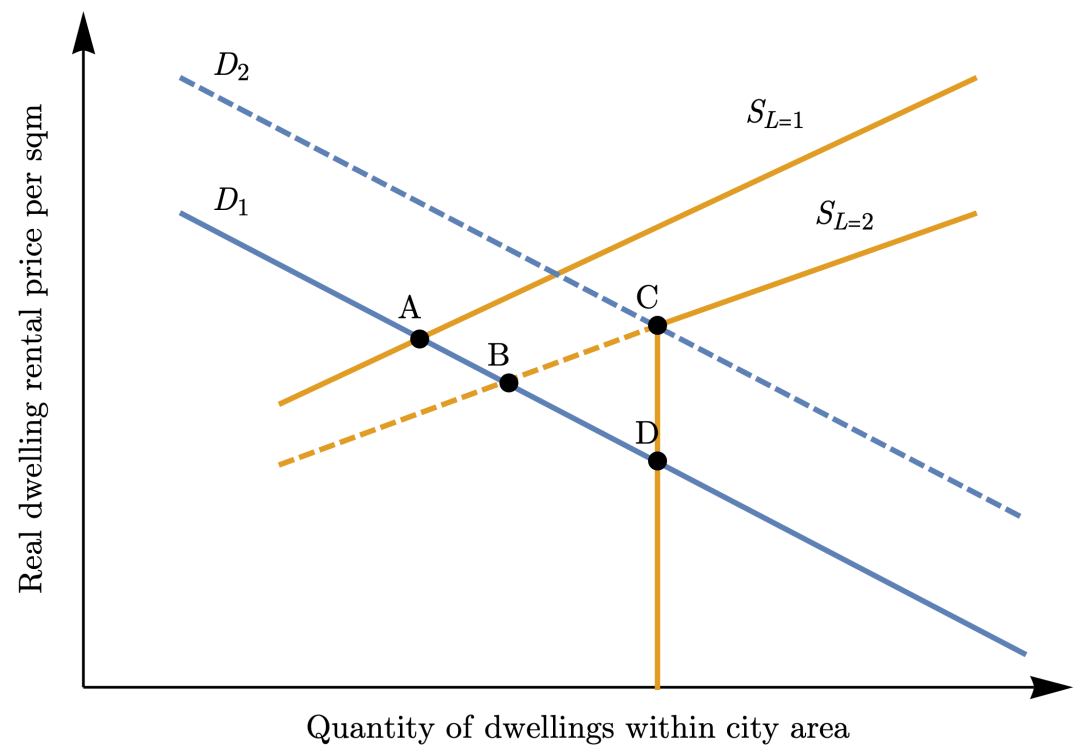

Figure 1: Static model equilibrium comparisons

The static model "portrays producers as able to costlessly adjust both their capital and land inputs from period to period." (Brueckner et al., 1987, p.826). The significance of this assumption cannot be overstated. It implies, for example, that if a landowner builds a detached dwelling at the optimal density today, when demand changes next month, they will 1) knock down the house and build a new apartment building at the new optimal density, and 2) pay only the difference in the construction cost between the house and the apartment building rather than the total apartment building construction cost. The costless adjustment assumption removes any question about development timing from the model. 


\section{Introducing time to the static model}

We depart from this standard static approach by looking at the housing stock adjustment process. For there to be a positive flow of new housing supply there must be undeveloped sites with profitable development options. The value of these sites prior to development is an option value based on the residual of prevailing housing asset prices less development cost. This is the source of land value in the static optimal density model and the real options approach to irreversible housing investment. ${ }^{8}$ Investment timing in a model of irreversible investment depends on the relative return to waiting or striking the development option.

In this section we show how a landowner's economic return from waiting to develop comes from the change in housing prices plus a premium arising from their ability to increase development density in response to price changes (putting aside the source of housing asset price changes for the moment). We adopt the cost-side assumptions about diseconomies of density from the static model, while breaking open the time dimension by allowing market asset price for housing, $P_{t}$, to vary over time rather than be the result of a static density equilibrium.

For any potential housing developer, the density that maximises land value is where the observed market price equals marginal development cost. Recall that marginal cost of additional density on a site $\frac{d C}{d D}=\beta C_{F C} D^{\beta-1}$. Therefore, the optimal density is

$$
D_{t}^{*}=\left(\frac{P_{t}}{\beta C_{F C}}\right)^{\frac{1}{\beta-1}} .
$$

Substituting this optimal density into Equation 2 under price-taking and a zero economic profits assumption (i.e. $R_{t}=P_{t} D_{t}-C\left(D_{t}\right)$ ) gives land value prior to development of

$$
R_{t}=P_{t}\left(\frac{P_{t}}{\beta C_{F C}}\right)^{\frac{1}{\beta-1}}-C_{F C}\left(\left(\frac{P_{t}}{\beta C_{F C}}\right)^{\frac{1}{\beta-1}}\right)^{\beta}
$$

The economic return to a landowner prior to development is the change in land value. This return can be determined as a function of price growth by taking the time derivative of land value in Equation 6. The result is

$$
\dot{R}_{t}=\frac{\beta}{(\beta-1)} \frac{\dot{P}_{t}}{P_{t}}\left(P_{t}\left(\frac{P_{t}}{\beta C_{F C}}\right)^{\frac{1}{\beta-1}}-C_{F C}\left(\left(\frac{P_{t}}{\beta C_{F C}}\right)^{\frac{1}{\beta-1}}\right)^{\beta}\right) .
$$

We can normalise this relationship to simplify it. The term in parentheses is Equation 6, or the current land value at the optimal density for an arbitrary sized plot of land. We can set this arbitrary land area to a size that has a current value equal to the price of a dwelling, or $R_{t}=P_{t}$. This turns a relative return of undeveloped land compared to dwellings into a relative rate of return on a dollar of value of land or housing, and simplifies this return to be

$$
\dot{R}_{t}=\frac{\beta}{(\beta-1)} \dot{P}_{t}
$$

\footnotetext{
${ }^{8}$ Some examples of land and housing supply research adopting this real options approach are Bulan et al. (2009); Yang \& Wu (2019); Tse (Jul 1998); Titman (1985).
} 
Since $\beta>1$, the $\beta /(\beta-1)$ term in Equation 8 captures the effect of higher density being optimal at higher prices, meaning that land values grow faster than prices if density is unconstrained. If $\beta=2$, for example, the capital gain of undeveloped land is twice the gain from a positive house price change due to the increase in optimal density at higher prices.

One way to simplify Equation 8 to reflect this intuition is to substitute $\omega$ for the $\beta /(\beta-1)$ term. Rather than $\beta$ reflecting the diseconomies of density, $\omega$ represents the cost-efficiency of higher density. The $\omega=1$ limiting condition then reflects a binding regulatory control on density (i.e. reflecting $\beta \rightarrow \infty$ ), and where a rising $\omega$ captures a declining $\beta$ (e.g. $\omega=2$ when $\beta=2$, and $\omega=5$ when $\beta=1.25$ ).

The intuition for this result can be seen with the help of Figure 2, which shows how the value of undeveloped land responds to market price changes. The orange shaded area is the land value of an undeveloped site when the market dwelling price is $P_{t}$ (i.e. where $P_{t}=M C$ and the $M C$ curve reflects the diseconomies of density). If this site remains undeveloped and the observed dwelling price rises to $P_{t+1}$, the land value change reflects the net effect of the increase in density and the increase in costs. The new optimal density at the $P_{t+1}$ price is $D_{t+1}$. The land value change is the sum of the areas $A$ and $B$ minus the area marked $C$, or $A+B-C$ (where $B>C$ ).

This is more than the value gain from price changes alone. For example, if density is constrained to $D_{t}$ because of planning regulations, the land value change is only the shaded area $A$, which captures just the dwelling price growth. In other words, the land area required for a single dwelling at the previous density would increase in value by the price change.

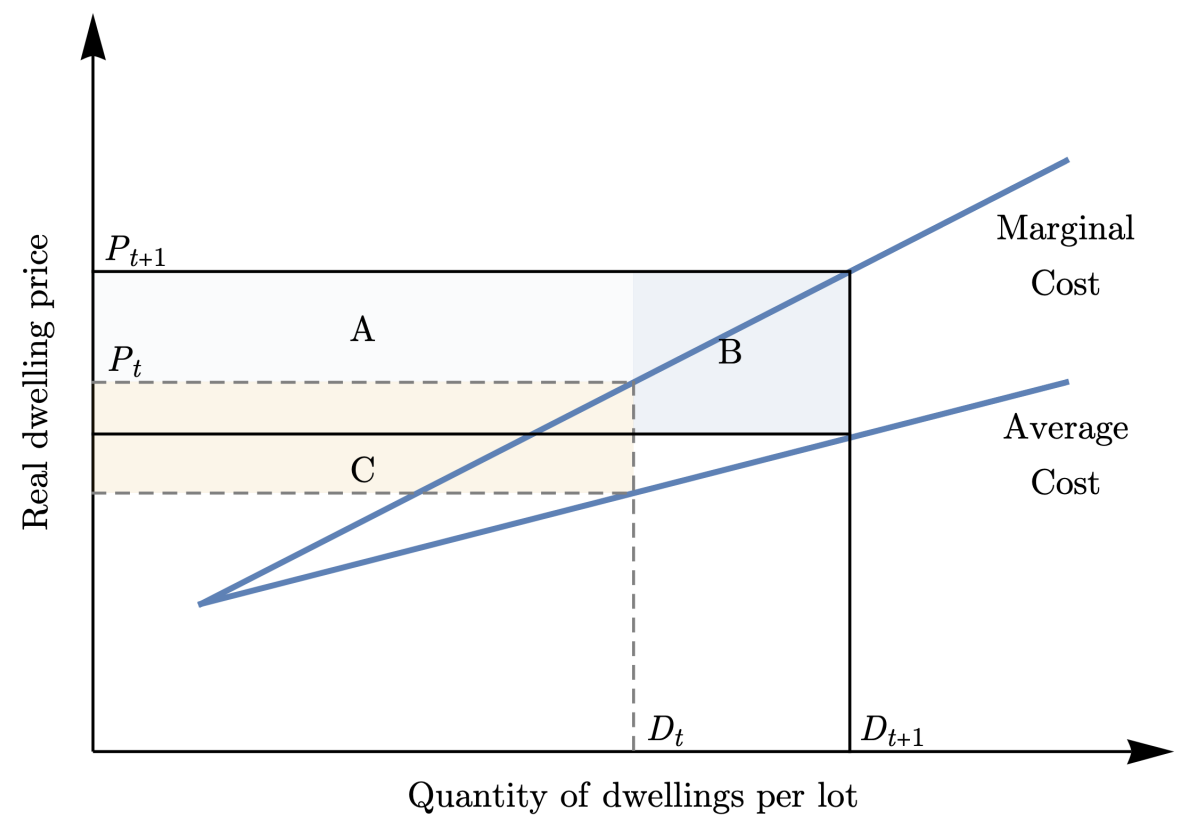

Figure 2: Source of land value growth in excess of dwelling price growth

This economic return to delaying housing development, in addition to land rents from lower value uses, must be given up when the decision to develop housing is made (a point made earlier in Murray (2020c)). An analogy with real options is that the smooth-pasting condition for a development option to be currently viable is when the expected total economic return 
from striking the development option exceeds the return from waiting. This is why real options models find that high price growth is related to delaying development, since it increases the economic return to waiting. Indeed, the effect of binding density constraints is to set $\omega \rightarrow 1$ (or, alternatively, $\beta \rightarrow \infty$ and $\frac{\beta}{(\beta-1)} \rightarrow 1$ ) lowering the hurdle return for development. As Murray (2020c) found, planning approvals were left to lapse at higher rates during periods of high price growth. This was perhaps due to market price growth increasing the optimal density and hence the return to delaying development.

\section{Optimising in the dynamic setting}

Thus far we have demonstrated that economic returns for landowners with potentially profitable housing development sites who do not develop come from the land value change, and depend on the cost-efficiency and regulation of housing density. The next question is how the market actions of housing lot producers determine a price growth equilibrium.

The new approach adopted here borrows from the financial asset trading literature, which finds that there are linear effects on asset prices from order book imbalances that are "inversely proportional to the market depth" (Gatheral \& Schied, 2013). New housing lot sales, being a sell-side event on a housing asset market order book, will have linear effects on price. We therefore can assume a relationship between market demand growth and price growth for housing assets in the following form

$$
\dot{P}_{t}=P_{t}\left(\dot{d}_{t}-a q_{t}\right)
$$

where $\dot{d}_{t}$ is the demand growth in the market for housing assets, and $a q_{t}$ captures the linear price effect from new supply, $q_{t}$, where a represents market thinness (the inverse of market depth). Note that this a parameter is quit different to the $\alpha$ parameter in the static model, which represents a preference for housing services by housing users.

We assume for now that all sellers in the housing asset market are able to observe their ownsupply effect on price growth. Under this monopolistic assumption the choice variable for each housing supplier, and the market as a whole, is how much land to allocate to new housing and sell to the market each period to maximise the present value of the flow of economic returns. This is the dynamic equivalent to profit maximisation. We can express this problem as per Equation 10, where the economic return to be maximised is the integral of the discounted flow of housing lot values that evolves due to the rate of new supply and its effect on the price level (denoted as $\left.R\left(P_{t}, q_{t}\right)\right)$.

$$
\max _{q_{t}} \int_{0}^{\infty} e^{-(i+\tau) t} R\left(P_{t}, q_{t}\right) d t
$$

Price is a state variable that evolves due to the change in housing asset market demand, $\dot{d}_{t}$, and the effect of new supply on the subsequent growth rate of housing prices, $a$. To incorporate the previous result of the optimal density varying with house price in our land value calculation (from Equation 7), we scale price growth to land value growth via $\omega$. Recall that $\omega$ represents the cost-efficiency of higher density, where a higher $\omega$ is associated with cheaper density additions, and where its minimum, $\omega=1$, represents a binding regulatory limit in density. Combined, this means that the change in land value is $\dot{R}_{t}=\omega P_{t}\left(\dot{d}_{t}-a q_{t}\right)$. 
The discount rate in Equation 10 includes the interest rate plus the rate of any taxes on holding the land levied on its value (as per Bentick (1979) and Mills (1981)), and hence reflects the economic cost of holding undeveloped land one extra period.

To solve this dynamic optimal control problem we apply Bellman's maximisation principle, which we represent in Equation 11. In this context the principle says that maximising the economic return from selling the same quantity of housing lots now and in any arbitrary later period will find the instantaneous optimal rate of sales. The first term is the economic return from selling $q_{t}$ housing lots in an initial period, which is the lot price in that period multiplied by the interest on that price and the saved taxes on holding. The second term is the return from selling the same number of lots to sell in a future period, accounting for first period sales, which is the change in land value of those future lots. The rate of new dwelling sales, $q_{t}$, that maximises this total return is the instantaneous optimal rate of dwelling sales that maximises the present value of the sequence of sales over time.

$$
\text { Value }_{t}=\max _{q_{t}}\{\underbrace{q_{t} R_{t}(i+\tau)}_{\text {Sell now }}+\underbrace{q_{t} \omega R_{t}\left(\dot{d}_{t}-a q_{t}\right)}_{\text {Sell later }}\}
$$

The solution is derived by first taking the derivative with respect to $q_{t}$ and setting to zero, (i.e. $\left.R_{t}\left(\omega\left(\dot{d}_{t}-2 a q_{t}\right)+i+\tau\right)=0\right)$, then solving for $q_{t} \cdot{ }^{9}$ This gives

$$
\text { Absorption Rate }=q_{t}^{*}=\frac{1}{2 a}\left(\dot{d}_{t}+\frac{(i+\tau)}{\omega}\right) .
$$

Substituting this equilibrium into the price growth of Equation 9, gives the market housing price growth rate in the dynamic equilibrium of

$$
\frac{\dot{P}_{t}}{P_{t}}=g_{t}^{*}=\frac{1}{2}\left(\dot{d}_{t}-\frac{(i+\tau)}{\omega}\right)
$$

This dynamic equilibrium housing price growth rate is positively related to demand growth, $\dot{d}_{t}$ (the price growth rate that would occur without new supply), and the cost-efficiency of density, $\omega$. This is the opposite to what is expected in static models, where cost-efficiency of density decreases the equilibrium price level. The dynamic equilibrium housing price growth rate is negatively related to the opportunity cost of waiting, which is the interest rate plus the property tax rate. We show the absorption rate equation graphically in Figure 3 . The total benefit of selling lots in a future period due to price growth is the blue line, with the dashed blue line showing marginal benefit, or $\dot{d}_{t}-2 \alpha q_{t}$. The marginal cost from selling a lot in the second period is the negative of the benefit of selling in the first period, or $-(i+\tau) / \omega$, the orange line. Since the marginal cost of selling today equals the marginal benefit in the second period, we get the equilibrium shown in Figure 3 at Point A. The intuition is that if the rate of new housing lot sales is higher than this equilibrium, there is a benefit from slowing the rate of sales so that the sequence of sales maximises the present value. For example, a rate higher than the equilibrium Point A, might involve five sales per month. But that fifth sale is depressing price growth by more than benefit from selling that lot today (the dashed blue line is below the orange line in

\footnotetext{
${ }^{9}$ To check second order conditions of a maximisation, take the second derivative with respect to $q_{t}$ to get $-2 a \omega p$.
} 
Figure 3). Reducing the sales rate to four sales per month will thus increase the present value of the balance sheet.

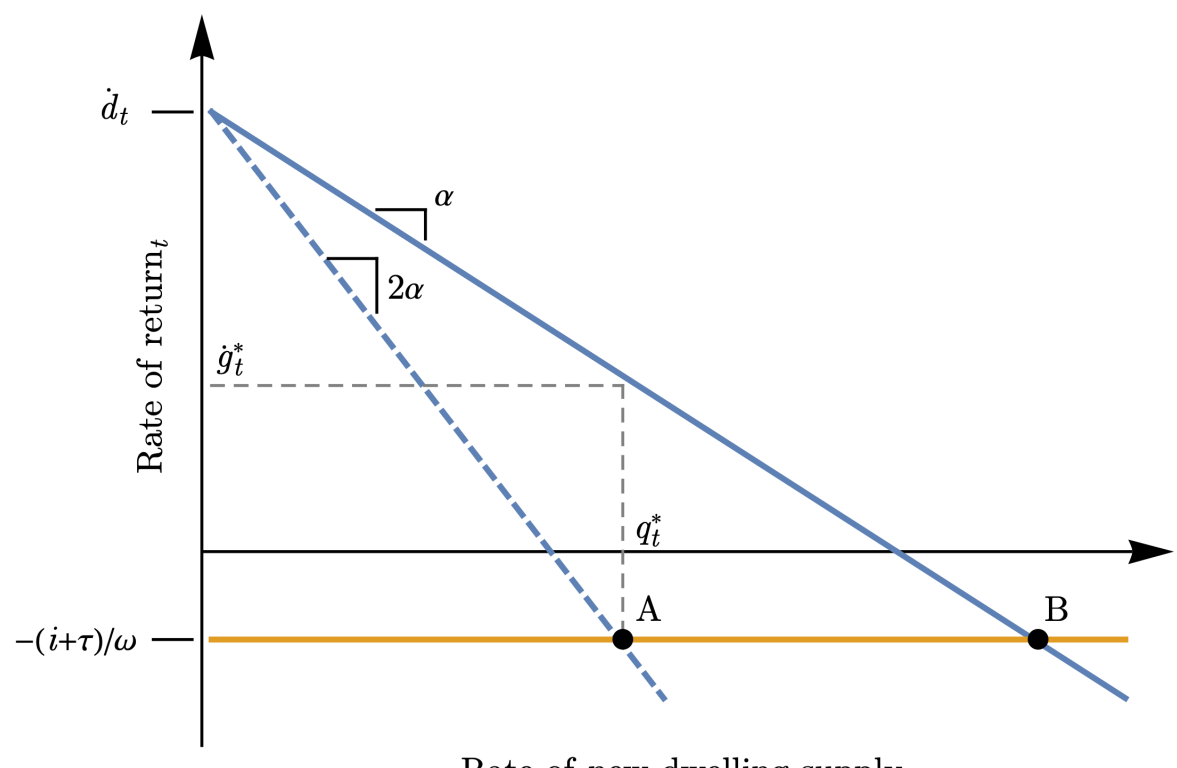

Rate of new dwelling supply

Figure 3: Graphical representation of the structure of the absorption rate equation

The equilibrium absorption rate derived here captures the case of a monopolistic representative owner of development sites who swaps vacant residential lots for cash and has the ability to change the size of the lots in response to market prices. It is also possible to derive a competitive market equilibrium in this dynamic setup. To do so requires assuming that each potential housing producer is a price-taker of the competitive equilibrium price growth rate. In this case, the price equals marginal cost condition is that $i+\tau=\omega\left(\dot{d}_{t}-a q_{t}\right)$, where $q_{t}$ is the equilibrium market new supply. This gives a competitive market equilibrium new housing supply of $q_{t}^{*}=\frac{1}{a}\left(\dot{d}_{t}+\frac{(i+\tau)}{\omega}\right)$, and is marked as Point B in Figure 3. The price growth rate at this point is $-(i+\tau) / \omega$.

However, it is not clear that a competitive equilibrium can be stable. Evidence shows individual housing developers choose their own rate of supply in response to market conditions (Murray, 2020c). Any landowner in a market where production is higher than the monopoly quantity in this model (somewhere between A and B in Figure 3) will find it individually advantageous to slow sales of new housing lots rather than increase them unless there is a perfect response by others to counteract this change. As shown by Huck et al. (2004, 2003), trial-and-error pricing approaches will find the monopoly equilibrium, even with a large number of potential suppliers. Regardless of the type of competition assumed, the direction of the parameter effects on the optimal rate of new supply is the same.

While it might seem that this modelling approach has ignored development costs, it merely takes development costs as given and nets out the effect of cost variation with density using $\omega$ to capture the land value residual. From an asset trade point of view, if a landowner develops housing they swap cash for construction inputs, then are paid cash for the land and constructed dwelling by the buyer, leaving on net an asset swap of cash for land. The same net asset trade happens if new housing lots are sold undeveloped to buyers who pay for their own construction. 
Netting out construction and development costs allows us to focus on the choice variables for landowners who are interested in maximising the value of their undeveloped land assets. In the Appendix we also derive the optimal choice for a representative landowner who owns all housing. In this setup, rather than earn interest and avoid land tax by selling housing lots, the conversion of lots to housing earns the difference between interest on development costs and housing rent (i.e. land rent), which is determined by the demand for housing services as per the static model.

\section{Comparison of results and discussion}

We summarise the difference in the direction of parameter effects between optimal housing supply rates and optimal density in Table 1.

Table 1: Parameter effects - optimal density and supply rate

\begin{tabular}{lcc}
\hline \hline & Density & Rate of supply \\
\hline 1. Dwelling service demand & + & Indirect \\
2. Per dwelling fixed costs & - & None \\
3. Diseconomies of density & - & + \\
4. Developable land area & + & None \\
5. Taxes on land value & None & + \\
6. Interest rates & - & + \\
7. Thinness of housing asset market $(a)$ & None & - \\
8. Growth of housing asset demand & None & + \\
\hline \hline
\end{tabular}

In the density model, $\alpha$ reflects housing rental service preferences, a component of housing service demand, while in the rate of supply absorption rate model, a represents the sensitivity of housing asset prices to new housing lot sales.

The economic reasons behind these discrepancies, and the implications of them, are discussed below.

1. Dwelling service demand

In the static density model, housing service demand (a function of housing preferences, population, income and dwelling stock) is positively related to the equilibrium stock of dwellings. In the absorption rate model, any effect from housing service demand occurs indirectly if, and when, housing rental prices affect the growth in demand for home buying.

2. Per dwelling fixed costs of development

The absorption rate model looks through development costs to net returns to land. Surprise shocks to development cost are immediately captured in lower land values without affecting timing decisions. However, announced future changes to development costs will affect timing decisions, with higher costs encouraging faster development, and lower costs slowing development (as found in Murray (2018)). In the optimal density model, higher fixed housing development costs always lead to lower equilibrium density and housing stock.

3. Diseconomies of density

Diseconomies of developing to higher density reduce the equilibrium quantity of housing stock, and increase the housing price, in the static model. However, the effect of this 
parameter on the rate of new supply is to increase the rate of new supply. This effect arises because its inverse, the cost-efficiency of density, provides a benefit to delaying development when housing asset demand is growing. A prediction of this absorption rate model (along with other real options models) is that areas with flexible planning and density should see slower development compared with nearby areas with strict density limits; a pattern evident so far in some studies (Letwin, 2018; Lewis, 2017; Woodcock et al., 2011).

4. Developable land area

The static model accounts for increases to developable land area with a new equilibrium at a lower housing service price, and a higher stock built at lower density. However, adding more lots to the stock of potentials does not change the absorption rate-larger subdivisions sell at the same rate per period in a given market as smaller ones.

5. Taxes on land value

Taxes in the absorption rate model have the effect of increasing the rate of supply because they are avoided by selling today, creating a cost to delay. In contrast, land value taxes have no effect on optimal density as they are applied to the land value, which is a derived value that has no effect on density choice.

By implication, land rents received prior to housing development for lower-value uses add to the cost of developing today in terms of the economic return forgone. The means that developed cities with legacy urban uses will be more likely to contain sites where housing development is delayed because of the return to waiting is higher than the return to striking the development option, even if by the logic of optimal density the site can be profitably redeveloped.

6. Interest rates

In the static model, the interest rate is inversely related to density when considered in terms of economic flows. Development cost in flow terms is the interest on the capital cost of development. Hence, interest rates act like a fixed cost in this model. In the absorption rate model, the effect of higher interest rates is to increase the cost of delay by increasing the benefit of developing today. This matches the real options model results discussed earlier, and has macroeconomic implications that do not seem to be well understood.

7. Thinness of the housing asset market

In the absorption rate model, housing asset markets have a finite depth and the trades required to sell new housing have linear price effects. This means that even if the asset price level is high, new housing supply can be slow if the market in that area is thin. This parameter may be quite important in situations where high price growth occurs with a low rate of new housing supply, or in situations where new locations are opened up for large scale housing development but few homebuyers are interested in that location.

8. Growth of housing asset demand

As noted by Ball et al. (2010) in their international review of supply elasticities, new supply is more responsive to changes in housing prices than price levels. The absorption rate model shows why this should be the case as the equilibrium rate of new supply is directly related to housing asset demand growth, and thus also price growth in the dynamic equilibrium. While it is implied in the static density model that a faster change in price level will result in a faster change in the housing stock, when interpreting a downwards price adjustment, the models provide different conclusions. For example, an increase in available land area creates a new equilibrium at a lower price and higher housing stock in the static model. But the absorption rate approach shows that the negative price change needed for that adjustment 
to occur would actually decrease the rate of new supply. Market supply-led downwards price adjustments are likely to be self-limiting due to dynamic economic incentives.

Comparing the static density approach and the dynamic absorption rate approach raises further questions for housing researchers and policymakers. First, the elasticity of housing supply concept makes little sense as traditionally understood as the horizontal summation of upward-sloping cost curves. Yes, costs increase with density. But costs do not necessarily increase with the rate of supply per period. It is also not clear that there is an optimal total stock of dwellings in a region, as this total stock is merely the integral of the equilibrium historical rate of supply.

Second, the expected positive relationship of price growth and new supply will confound many empirical approaches that attempt to tease out the effect of supply on prices. Quantifying the effect of planning regulations on the rate of new supply, and hence on dwelling rents and prices needs more careful consideration. Density and height, for example, are not useful proxies for the rate of supply. Furthermore, dwellings rents should be considered as measures of the economic price of housing services, rather than prices, which can vary independently of the economic price of housing (rents) due to asset-pricing factors such as interest rates and expectations. However, if the new housing market is supplied by developers who are asset managers, these asset pricing factors will have large effects on new supply.

The main policy lesson from this exercise is that increasing the rate of housing supply can be achieved by increasing the cost to delay relative to developing today. This may involve taxes for holding land, time limits or financial penalties for retaining undeveloped land in areas planned for higher density. It shows that in periods of high demand growth that prices will always rise as it will not be optimal for landowners to develop so fast that they do not capture some of those price gains for themselves in the value of their undeveloped land.

\section{References}

Ball, Michael, Meen, Geoffrey, \& Nygaard, Christian. 2010. Housing supply price elasticities revisited: Evidence from international, national, local and company data. Journal of Housing Economics, 19(4), 255-268.

Bentick, Brian L. 1979. The impact of taxation and valuation practices on the timing and efficiency of land use. Journal of Political Economy, 87(4), 859-868.

BrueCKner, Jan K, et al. 1987. The structure of urban equilibria: A unified treatment of the Muth-Mills model. Handbook of regional and urban economics, 2(20), 821-845.

Bulan, Laarni, Mayer, Christopher, \& Somerville, C. Tsuriel. 2009. Irreversible investment, real options, and competition: Evidence from real estate development. Journal of Urban Economics, 65(3), 237-251.

Capozza, Dennis, \& Li, Yuming. 1994. The Intensity and Timing of Investment: The Case of Land. The American Economic Review, 84(4), 889-904.

Capozza, Dennis R, \& Li, Yuming. 2002. Optimal land development decisions. Journal of Urban Economics, 51(1), 123-142.

Cont, Rama, Kukanov, Arseniy, \& Stoikov, Sasha. 2013. The Price Impact of Order Book Events. Journal of Financial Econometrics, 12(1), 47-88.

Cowan, JiLl. 2019. Should California Get Rid of Single-Family Zoning? New York Times, June 20. 
DiPasquale, Denise. 1999. Why don't we know more about housing supply? The Journal of Real Estate Finance and Economics, 18(1), 9-23.

Gatheral, Jim, \& Schied, Alexander. 2013. Dynamical models of market impact and algorithms for order execution. HANDBOOK ON SYSTEMIC RISK, Jean-Pierre Fouque, Joseph A. Langsam, eds, 579-599.

Glaeser, Edward, \& Gyourko, Joseph. 2018. The Economic Implications of Housing Supply. Journal of Economic Perspectives, 32(1), 3-30.

Glaeser, Edward L, Gyourko, Joseph, \& Saks, Raven. 2005. Why is Manhattan so expensive? Regulation and the rise in housing prices. The Journal of Law and Economics, 48(2), 331-369.

Gyourko, Joseph, \& Molloy, Raven. 2015. Regulation and housing supply. Pages 12891337 of: Handbook of Regional and Urban Economics, vol. 5. Elsevier.

Hansen, Matt. 2020. Adopt the Missing Middle Housing Act and provide zoning regulation requirements for certain cities. Tech. rept. Nebraska 106th Legislature.

Huck, Steffen, Normann, Hans-Theo, \& Oechssler, Jörg. 2003. Zero-knowledge cooperation in dilemma games. Journal of Theoretical Biology, 220(1), 47-54.

Huck, Steffen, Normann, Hans-Theo, \& Oechssler, Jörg. 2004. Through trial and error to collusion. International Economic Review, 45(1), 205-224.

Jou, JyH-BAng, \& LeE, TAN. 2007. Do tighter restrictions on density retard development? The Journal of Real Estate Finance and Economics, 34(2), 225-232.

Kendall, Ross, \& Tulip, Peter. 2018. The Effect of Zoning on Housing Prices. Research Discussion Paper 2018-03. Reserve Bank of Australia.

Kulish, Mariano, Richards, Anthony, \& Gillitzer, Christian. 2012. Urban Structure and Housing Prices: Some Evidence from Australian Cities. Economic Record, 88(282), 303322 .

Lange, Rutger-Jan, \& Teulings, Coen N. 2018. The option value of vacant land and the optimal timing of city extensions. CEPR Discussion Paper No. DP12847.

LEES, KIRDAN. 2018. Quantifying the costs of land use regulation: Evidence from New Zealand. New Zealand Economic Papers, May, 1-25.

Lendlease. 2019. Annual Report 2018-19. Tech. rept.

Letwin, Oliver. 2018 (June). Independent Review of Build Out Rates - Annexes. Tech. rept. Ministry of Housing, Communities and Local Government.

Lewis, SAlly AnNe. 2017. Reconciling Australian planning, development and housing outcomes. Ph.D. thesis, Faculty of Architecture, Design and Planning. University of Sydney.

Manville, Michael, Lens, Michael, \& Monkkonen, Paavo. 2020. Zoning and affordability: A reply to Rodríguez-Pose and Storper. Urban Studies, 0042098020910330.

Manville, Michael; Monkkonen, PaAvo; Lens Michael. 2019. It's Time to End SingleFamily Zoning. Journal of the American Planning Association, 1-7.

MHCLG. 2020 (August). Planning for the future: White paper. Tech. rept. Ministry of Housing, Communities and Local Government. 
Mills, David E. 1981. The non-neutrality of land value taxation. National Tax Journal, 34(1), 125-129.

Monkkonen, PaAvo. 2019. The elephant in the zoning code: Single family zoning in the housing supply discussion. Housing Policy Debate, 29(1), 41-43.

Murphy, Alvin. 2018. A dynamic model of housing supply. American Economic Journal: Economic Policy, 10(4), 243-67.

Murray, Cameron K. 2018. Developers pay developer charges. Cities, 74, 1-6.

Murray, Cameron K. 2020a. The Australian housing supply myth. Open Science Foundation.

Murray, Cameron K. 2020b. Marginal and average prices of land lots should not be equal: A critique of Glaeser and Gyourko's method for identifying residential price effects of town planning regulations. Environment and Planning A: Economy and Space, 0308518X20942874.

Murray, Cameron K. 2020c. Time is money: How landbanking constrains housing supply. Journal of Housing Economics, 49, 101708.

O'Flaherty, Brendan. 2003. Commentary (on Glaeser and Gyourko). Federal Reserve Bank of New York Policy Review, 9(2), 41-43.

PACIOREK, Andrew. 2013. Supply constraints and housing market dynamics. Journal of Urban Economics, 77, 11-26.

Pines, DAVID. 1989. Handbook of regional and urban economics, volume 2: Urban economics,: edited by Edwin S. Mills (North-Holland, Amsterdam, 1987). Regional Science and Urban Economics, 19(4), $646-658$.

Quigley, John M, \& Rosenthal, LARry A. 2005. The effects of land use regulation on the price of housing: What do we know? What can we learn? Cityscape, 69-137.

Rodríguez-Pose, Andrés, \& Storper, Michael. 2020. Dodging the burden of proof: A reply to Manville, Lens and Mönkkönen. Urban Studies, 0042098020948793.

Somerville, C Tsuriel. 2005. Zoning and Affordable Housing: A Critical Review of Glaeser and Gyourko's Paper. Canada Mortgage and Housing Corporation.

Titman, Sheridan. 1985. Urban land prices under uncertainty. The American Economic Review, 75(3), 505-514.

Tse, Raymond Y C. Jul 1998. Housing price, land supply and revenue from land sales. Urban Studies, 35(8), 1377-1377.

Wegmann, Jake. 2019. Death to Single-Family Zoning. . . and New Life to the Missing Middle. Journal of the American Planning Association, 86(1), 113-119.

Wiener, SCOTT. 2020. SB-50 Planning and zoning: housing development: streamlined approval: incentives. Tech. rept. California State Senate.

Woodcock, Ian, Dovey, Kim, Wollan, Simon, \& Robertson, Ian. 2011. Speculation and resistance: constraints on compact city policy implementation in Melbourne. Urban policy and research, 29(4), 343-362.

YANG, ZAN, \& WU, Shuping. 2019. Land acquisition outcome, developer risk attitude and land development timing. The Journal of Real Estate Finance and Economics, 59(2), 233-271. 
Yglesias, MatThew. 2012. The rent is too damn high: What to do about it, and why it matters more than you think. Simon and Schuster.

\section{Appendix: Representative housing owner absorption rate}

A more general version of this absorption rate approach assumes the representative agent not only supplies new housing lots but owns all housing once developed. In this model environment, the dynamic maximisation problem is as per Equation 14.

$$
\max _{q_{t}} \int_{0}^{\infty} e^{-i t} \operatorname{Return}\left(Q_{t}, q_{t}\right) d t .
$$

Notably, the effect of land holding taxes is removed from the discounting process as the representative agent pays these taxes with or without housing on the site and it therefore does not enter the timing decision. Here, the housing stock, $Q_{t}$, is the state variable that evolves subject to new dwelling supply, $q_{t}$, and the dwelling value, $P_{t}$, is the capitalised value of the housing rent resulting from that housing stock at a fixed capitalisation rate, $i$.

The two economic returns of interest for solving this maximisation problem are for (1) converting a lot into housing, and (2) retaining a housing lot undeveloped. The return from converting a lot into housing is the rent minus the interest on development cost, plus the dwelling price growth (the capital gain), minus any land rents from lower value uses on the site that must be given up. We show this in the first term of Equation 15 which shows the problem redefined as an optimisation of the instantaneous rate of new supply according to Bellman's maximisation principle. The economic return from delaying converting a lot into housing is the capital gain of that land, which is the dwelling price gain scaled by $\omega$.

$$
\operatorname{Return}_{t}=\underbrace{q_{t}\left(p_{t}+\dot{P}_{t}-C_{F C} i-r_{L}\right)}_{\text {Net dwelling return }}+\underbrace{q_{t}\left(\omega \dot{P}_{t}\left(q_{t}\right)\right)}_{\text {Land capital gain }}
$$

To determine housing rents we borrow directly from the static model where housing rents are determined by incomes, housing preferences, and housing stock, such that $p_{t}=\alpha y_{t} / Q_{t}$. Price growth forms part of the return to owning housing and in this setup is the capitalised time derivative of rents. The cost of development is scaled so that at the current optimal density $C_{F C}$ is the per dwelling average cost, meaning that in annual flow terms the development costs is $C_{F C} i$. The forgone rents from lower value uses are $r_{L}$. The return to delay is represented by the capital gains that occur on land in the absence of development, which in this case is the capitalised change in rent (the capital gain) of the dwelling scaled by the diseconomies of density relationship $\omega$ to capture the change in optimal density with price. The complete problem setup is in Equation 16.

$$
\left.\operatorname{Return}_{t}=\max _{q_{t}}\{q_{t} \underbrace{\left(\frac{\alpha y_{t}}{Q_{t}}+\frac{\frac{\alpha \dot{y}_{t}}{Q_{t}}-\frac{\alpha y_{t} q_{t}}{Q_{t}^{2}}}{i}-C_{F C} i-r_{L}\right)}_{\text {Net rent plus cap. gain (now) }}+q_{t} \underbrace{\left(\omega \frac{\alpha \dot{y}_{t}}{Q_{t}-\frac{\alpha y_{t} q_{t}}{Q_{t}^{2}}}\right.}_{\text {Scaled cap. gain (later) }})\right\}
$$


The problem is solved by taking the derivative of the return with respect to $q_{t}$ and setting to zero, giving

$$
\frac{\alpha y_{t}}{Q_{t}}-\frac{2 \alpha y_{t} q_{t}}{i Q_{t}^{2}}-C_{F C}-r_{L}+\frac{\omega \alpha \dot{y}_{t}}{i Q_{t}}-\frac{2 \omega \alpha y_{t} q_{t}}{i Q_{t}^{2}}=0
$$

then solving for $q_{t}$. Second order conditions for a maximum are confirmed by the second derivative result of $-\frac{(1+\omega) 2 \alpha y_{t}}{i Q_{t}^{2}}$. Solving for $q_{t}$ and rearranging provides the solution for the equilibrium new housing supply in Equation 17.

$$
q_{t}^{*}=\underbrace{Q}_{\text {Stock }} \frac{1}{2}(\underbrace{\frac{\dot{y}_{t}}{y_{t}}}_{\text {Income growth rate }}+\underbrace{\frac{i}{(1+\omega)}}_{\text {Intertemporal cost }}(\underbrace{1-\frac{Q\left(C_{F C} i+r_{L}\right)}{\alpha y_{t}}}_{\text {Land rent share of gross rent }}))
$$

The first term in parentheses is the income growth rate. The second term is the product of the land rent share of gross dwelling rent (which is bound by 0 and 1 for profitable developments) and the intertemporal cost of earning that land rent which is the interest rate augmented by the efficiency of density, $\omega$.

The rent growth rate that results at this optimal rate of supply (the change in rent divided by rent) is $\frac{\dot{y}_{t}}{y_{t}}-\frac{q_{t}}{Q_{t}}$. Intuitively this shows that if the rate of growth of supply exceeds the rate of income growth then prices will fall. Substituting our optimal supply, $q_{t}^{*}$ for $q$ provides the following housing rental growth rate (and hence price growth rate when the capitalisation rate is fixed) with the equilibrium rate new supply.

$$
\frac{\dot{r}_{t}}{r_{t}}=g_{t}^{*}=\frac{1}{2 i}\left(\frac{\dot{y}_{t}}{y_{t}}+\frac{i}{(1+\omega)}\left(\frac{Q\left(C_{F C} i+r_{L}\right)}{\alpha y_{t}}-1\right)\right)
$$

We know that $\frac{Q\left(C_{F C} i+r_{L}\right)}{\alpha y_{t}}-1<0$ for any feasible development. Hence the price growth will be less than half the demand growth $\left(\frac{\alpha \dot{y}_{t}}{Q}\right)$ in this dynamic equilibrium.

How much less depends on a number of factors. An ability to increase density cheaper, or a higher $\omega$, will increase the price growth rate, as well a higher ratio of development costs in flow terms compared to the housing rent. The effect of interest rates depends on the relative effect on the cost of borrowing for development (in the $C_{F C} i$ term) and its effect on inter-temporal optimisation (in the $i /(1+\omega)$ term).

The main difference between the representative dwelling owner agent problem and the agent selling housing lots is the effect of the net land rent. In this formulation, the land rent from its use as housing is forgone when delaying development rather than the interest on land value. In this problem setup, reductions in the fixed cost of housing development increase net land rents from developing housing and accelerate supply. The same effect can be achieved by reducing rental income from lower value uses, or increasing holding costs in a way that reduces the net rental income while delaying housing development. In places where built-to-rent landlords dominate the housing market, these effects may be important.

Another difference is that the own-price effect from developing housing comes via the housing rental market rather than the housing asset market, i.e. $\alpha$ reflects the sensitivity of rent to 
new rental supply, while $a$ represents the sensitivity of price to new housing lot sales. Lastly, the demand growth effect in this model comes via population and/or income growth, which translates into rental housing demand. 